\title{
PEMBUATAN PUPUK KOMPOS CAIR DARI BUAH LIMBAH DI SENTRA PENJUALAN BUAH-BUAHAN DESA TEBAT MONOK KABUPATEN KEPAHIANG
}

\section{MAKING OF LIQUID COMPOST FERTILIZER FROM WASTE OF FRUIT AT FRUITS SALES CENTER IN TEBAT MONOK VILLAGE KEPAHIANG DISTRICT}

\author{
Oleh: \\ Deselina, Erniwati, dan Bilman WS \\ Jurusan Kehutanan Fakultas Pertanian Universitas Bengkulu
}

\begin{abstract}
Increasing the amount of waste to be balanced with the public's awareness of environmental commercialize clean and healthy. One way to reduce the amount of waste is by using fruit waste into liquid compost. Therefore, raw materials derived from the papaya fruit, then the resulting compost is liquid compost flavored papaya. The purpose of this DIPA fund service activities is increasing the skills of the youth in particular members of youth, housewives and members of the PKK on how to make liquid compost, can produce good quality liquid compost, improve understanding of the society about the importance of household waste management, and increase family income in the Village of Tebat Monok Kepahiang District. Service activities are carried out by the method of education and training on the importance of waste management, utilization waste environment, and how marketing the product waste, and training on knowledge of how to make liquid compost quality and composting demonstration of liquid and liquid compost application on crops. The results show that the devotion of liquid composting of fruit waste in the Fruits Sales Center at Village Tebat Monok is one right step in processing the fast decaying fruit waste (papaya). This liquid composting, in addition to adding the fruit merchant skills in managing waste, businesses can also be used as an attempt to increase the income of the traders in the village.
\end{abstract}

Keywords: Liquid Compost, Waste, Sales

\section{PENDAHULUAN}

Buah-buahan merupakan salah satu produk tanaman holtikultura yang tumbuh subur di negara kita. Buah-buahan banyak mengandung vitamin dan mineral yang dibutuhkan oleh tubuh. Buah-buahan diperlukan oleh tubuh karena tubuh tidak dapat memproduksi vitamin dan mineral. Dengan mengkonsumsi buah-buahan berarti kita membantu meningkatkan daya tahan tubuh.

Buah merupakan salah satu produk pertanian yang umumnya tidak dapat bertahan lama atau mudah busuk. Apalagi bila ditempatkan tanpa menggunakan fasilitas pendingin atau hanya pada suhu kamar. Tidak semua konsumen bahkan pedagang buah memiliki 
fasilitas tersebut, terlebih-lebih pedagang buah yang berlokasi di pinggir-pinggir jalan. Terkadang karena sifat buah yang mudah busuk tersebut maka tidak semua buah yang dimiliki dapat dikonsumsi oleh konsumen. Demikian juga dengan buah yang dijual oleh para pedagang buah belum tentu semua habis terjual. Hal ini bisa dikarenakan buah tersebut sudah tidak layak jual, cacat, mahal atau sebab lain sehingga buah-buahan tersebut menjadi limbah dan umumnya dibuang. Sudah menjadi pemandangan umum setiap hari terdapat buah limbah di keranjang sampah para pedagang.

Buah-buahan yang masih di pohon dan matang terkadang sudah jatuh ke tanah sebelum sempat dipetik oleh pemiliknya. Terlebih-lebih untuk jenis-jenis yang mudah rontok seperti jambu air dan belimbing. Biasanya buah-buahan yang sudah jatuh tersebut tidak dikonsumsi karena fisiknya sudah rusak dan akhirnya buah-buah tersebut menjadi limbah dan dibuang. Buah-buah limbah ini akhirnya menjadi sampah . Dapat dibayangkan jumlah sampah dari buah limbah buah yang dihasilkan oleh para pedagang buah setiap hari. Jumlah ini bisa bertambah pada saat musim buah, dimana banyak buah yang berserakan di bawah pohon di pekarangan penduduk.

Sampah atau waste (Inggris) pada prinsipnya adalah suatu bahan yang terbuang atau dibuang dari sumber aktivitas manusia maupun alam yang belum memiliki nilai ekonomis, dan bisa berbentuk padat, cair dan gas sedangkan berdasarkan sifatnya dipilah menjadi sampah organik dan anorganik. Di tengah padatnya aktivitas manusia penanganan sampah menjadi permasalahan serius yang belum bisa tertangani dengan tuntas, terutama di kotakota besar. Pasalnya rata-rata tiap orang per hari dapat menghasilkan sampah 1-2 kg dan akan terus bertambah sejalan dengan meningkatnya kesejahteraan gaya hidup masayarakat (Hadisuwito, 2010). Sampah yang tidak mendapat pengananan serius bisa mengakibatkan pencemaran baik polusi udara, polusi air, maupun polusi tanah. Apabila masalah ini tidak tertangani secara bijaksana maka cepat atau lambat sampah akan menenggelamkan kehidupan dengan beragam dampak negatif yang ditimbulkannya (Basriyanta, 2007).

Di Indonesia, sekitar 60-70\% dari total volume sampah yang dihasilkan merupakan sampah basah dengan kadar air antara 65-75\%. Sumber sampah terbanyak berasal dari pasar tradisional dan pemukiman. Sampah pasar tradisional, seperti pasar lauk pauk dan sayur mayur membuang hampir 95\% sampah organik. Sementara itu sampah di daerah pemukiman jauh lebih beragam,namun $75 \%$ dari total sampah tersebut termasuk sampah organik. Jika ditinjau dari pengolahannya sampah jenis ini akan mudah ditangani (Tim Penulis PS, 2008). Menurut data Kementrian Lingkungan Hidup sampah organik yang dikomposkan baru berkisar 1-6\%, sedangkan sisanya lebih banyak dibakar, ditimbun dan dibuang ke sungai dan ke Tempat Penampungan Akhir (TPA) (Hadisuwito, 2010).

Dampak negatif sampah mungkin tidak bisa dihilangkan secara tuntas sampai ke akarnya, namun usaha pengelolaan sampah dan pengolahan sampah yang telah dilakukan berbagai pihak turut memberikan kontribusi guna menanggulangi problematika sampah. Kerja keras pemerintah tentu tidak akan berjalan mulus tanpa partisipasi dan respon langsung masyarakat. 
Beberapa upaya yang umum dilakukan oleh masyarakat yaitu penumpukan, pembakaran, sanitary landfill dan pengomposan. Pengelolaan sampah dengan cara pengomposan atau mengubahnya menjadi pupuk merupakan alternatif terbaik. Secara gamblang kompos bisa diartikan sebagai pupuk alami yang terbuat dari bahan-bahan hijauan dan bahan organik lain yang sengaja ditambahkan untuk mempercepat pembusukan. Kompos umumnya berbentuk padat namun dapat juga berbentuk cair. Buah limbah dapat dijadikan bahan baku dalam pembuatan kompos cair. Pengolahan sampah menjadi kompos tidak hanya mengurangi problematika sampah kota namun juga telah menyulapnya menjadi rupiah karena tren membuat kompos selain dipakai untuk keperluan sendiri dapat juga dijual pada yang memerlukannya.

Desa Tebat Monok yang terletak di Kecamatan Kepahiang Kabupaten Kepahiang dan berjarak $\pm 3 \mathrm{Km}$ dari pusat kota Kepahiang merupakan sentra penjualan buah-buahan di Kepahiang. Desa Tebat Monok yang terletak disepanjang jalan raya Bengkulu-Curup memiliki ciri tersendiri yaitu dengan adanya para pedagang buah di sepanjang jalan. Salah satu buah yang mendominasi adalah pepaya. Pepaya merupakan buah yang mudah busuk, salah satu penyebabnya kulit buah yang mudah rusak. Kondisi ini merupakan salah penyebab bertambahnya volume sampah khususnya dari buah limbah.

Keberadaan sampah hingga saat ini masih cenderung dianggap sesuatu yang tidak bermanfaat dan bahkan merugikan. Sampah dapat menyebabkan berbagai macam penyakit seperti diare, tifus dan muntaber; mencemari lingkungan misalnya menimbulkan bau yang tidak sedap dan berubahnya ekosistem perairan biologis dan berbagai dampak sosial ekonomi. Meningkatnya jumlah sampah harus diimbangi dengan kesadaran masyarakat untuk mengusahakan lingkungan yang hidup yang bersih dan sehat. Salah satu cara mengurangi jumlah sampah adalah dengan memanfaatkan buah limbah menjadi pupuk kompos cair.

Tujuan dari kegiatan ini adalah:

1. Meningkatnya ketrampilan para pemuda khususnya anggota karang taruna, para pedagang buah dan para ibu rumah tangga anggota kelompok PKK dalam membuat pupuk kompos cair.

2. Dapat diproduksinya pupuk kompos cair yang bermutu baik.

3. Meningkatnya pemahaman penduduk mengenai pentingnya pengelolaan limbah rumah tangga bertambahnya pendapatan keluarga dan pedagang buah di Desa Tebat Monok Kecamatan Kepahiang Kabupaten Kepahiang.

Manfaat kegiatan ini adalah:

1. Menambah pengetahuan penduduk dalam mengelola sampah.

2. Menciptakan lapangan kerja baru bagi pemuda khususnya anggota karang taruna dan ibu rumah tangga sehingga menambah pendapatan keluarga.

3. Karang taruna dan kelompok PKK memiliki Composter yang dapat dipakai untuk membuat pupuk kompos dari bahan lain selain limbah buah-buahan.

4. Terciptanya lingkungan yang bersih dan sehat. 
5. Terbentuknya jalinan kerjasama antara para pedagang buah, kelompok PKK dan Karang Taruna Desa Tebat Monok dengan LPPM UNIB.

\section{METODE PENGABDIAN}

\section{Waktu dan Tempat Kegiatan}

Kegaitan pengabdian pada masyarakat dilakukan pada Bulan September di Balai Desa Tebat Monok Kecamatan Kepahiang.

\section{Khalayak Sasaran}

Sasaran dari kegiatan ini adalah anggota karang taruna, para anggota kelompok PKK dan para pedagang buah di Desa Tebat Monok Kecamatan Kepahiang Kabupaten Kepahiang.

\section{Metode Penerapan IPTEKS}

Transformasi teknologi yang efektif bagi masyarakat di Desa Tebat Monok adalah menggunakan metode penyuluhan, pelatihan dengan banyak membuat demonstrasi atau melakukan praktek langsung diiringi pendampingan (White, 1990). Oleh karena itu dalam kegiatan penerapan IPTEKS digunakan metode:

a. Penyuluhan dan tatap muka: mengenai pentingnya pengelolaan sampah, pemanfaatan limbah lingkungan dan mengenai cara pemasaran produk limbah

b. Pelatihan: pengetahuan cara membuat pupuk kompos cair yang berkualitas

c. Demonstrasi: pembuatan pupuk kompos cair dan aplikasi pupuk kompos cair pada tanaman.

\section{HASIL DAN PEMBAHASAN}

Kegiatan pengabdian pada masyarakat ini dilaksanakan Bulan Agustus-September 2013. Kegiatan lapangan diawali dengan sosialisasi kegiatan yaitu dengan mendatangi Kepala Desa Tebat Monok Bapak Padila Sandi dan para pedagang buah untuk menjelaskan tujuan diadakannya kegiatan pengabdian ini. Berdasarkan hasil interview diketahui bahwa para pedagang buah di Tebat Monok belum pernah mendapatkan informasi mengenai penanganan buah limbah.

Kegiatan pengabdian dilakukan dengan metode penyuluhan dan demonstrasi yang dilakukan di Balai Desa Tebat Monok. Kegiatan dihadiri oleh para pedagang buah, ibu-ibu Kelompok PKK dan para Kelompok Tani.

Secara umum pelaksanaan kegiatan pengabdian Ipteks bagi masyarakat berjalan lancar. Penyuluhan dilakukan untuk menyampaikan pengetahuan mengenai pentingnya pengelolaan limbah, pemanfaatan limbah lingkungan dan mengenai cara pemasaran produk limbah. 
Ada tiga cara yang mudah untuk mengatasi masalah limbah yaitu dengan prinsip 3R yaitu:

1. Reduce (Mengurangi): sebisa mungkin lakukan minimalisasi barang atau material yang dipergunakan,

2. Reuse (Memakai kembali): sebisa mungkin pilihlah barang-barang yang bisa dipakai kembali dan hindari pemakaian barang-barang yang hanya bisa sekali digunakan (disposable),

3. Recycle (daur ulang): sebisa mungkin barang-barang yang sudah tidak terpakai didaur ulang, walaupun tidak semua barang bisa didaur ulang.

Prinsip 3R ini bisa menjadi pedoman sederhana untuk membantu kita dalam mengurangi sampah di rumah (Suryati, 2009).

Pada acara penyuluhan diperkenalkan juga beberapa jenis pupuk kompos selain pupuk kompos cair. Selain itu diperkenalkan juga cara pembuatan pupuk kompos yang cepat dengan memperkenalkan aktivator. Beberapa aktivator yang bisa dipakai adalah Aktivator Orgadec, Stardec, EM-4, Harmony dan Fix-Up dan Boisca dengan keunggulan masing-masing (Indriani, 2008).

Pembuatan pupuk kompos cair dari buah limbah bagi pedagang buah di Sentra Penjualan Buah-buahan Desa Tebat Monok merupakan hal yang baru. Pepaya sebagai salah satu komoditi para pedagang dikenal sebagai buah yang cepat membusuk. Selama ini buah pepaya yang sudah membusuk hanya dibuang begitu saja atau menjadi makanan ternak. Dengan dimanfaatkannya buah limbah ini menjadi pupuk kompos cair menjadi salah satu usaha mengurangi limbah sekaligus menambah penghasilan para pedagang buah. Pada kesempatan tersebut diperkenalkan juga cara memasarkan produk pupuk kompos cair. Salah satu yang menjadi daya tarik bagi pembeli adalah kemasan produk. Oleh karena yang menjadi khalayak sasaran adalah para pedagang buah maka usaha pemasaran bukan merupakan suatu permasalahan.

Pembuatan pupuk kompos cair dengan Metode Satu-Dua-Tiga yang sangat mudah dilakukan oleh para khalayak sasaran membuat para peserta demonstrasi menjadi semakin bersemangat. Metode satu-dua-tiga berarti setiap satu kilogram buah papaya yang sudah membusuk dicampurkan dengan dua ons gula pasir/gula merah dan tiga liter air sumur ke dalam ember (composter). Masukkan buah papaya yang sudah dirajang ke dalam karung beras kemudian masukkan karung tersebut ke dalam ember yang sudah berisi campuran air sumur dan gula pasir/gula merah. Dengan pengadukan setiap tiga hari maka dalam satu bulan dapat dihasilkan pupuk kompos cair (biang atau lindi) siap dipanen sementara kompos yang terdapat dalam karung dapat dijadikan bahan kompos padat. Dengan demikian dalam satu rangkaian kegiatan pembuatan pupuk kompos cair dapat juga dihasilkan pupuk kompos padat. Aplikasi pupuk kompos cair ke tanaman dapat dilakukan dengan terlebih dahulu memcampurkan setiap satu liter biang/lindi ke dalam 100 liter air, baru disiramkan ke dalam tanaman. 
Untuk memotivasi khalayak sasaran untuk membuat pupuk kompos cair maka Tim Pengabdian menyerahkan dua set peralatan Composter untuk membuat pupuk kompos cair. Selain dipergunakan untuk pupuk kompos cair, Composter ini juga dapat dipakai untuk membuat pupuk kompos padat.

Dalam proses pengomposan ada beberapa keuntungan yang dapat diambil antara lain: 1) kompos merupakan pupuk oragnik ramah lingkungan, 2) bahan yang diolah menjadi kompos sudah tersedia dan tidak perlu membeli, 3) masyarakat dapat membuatnya sendiri, tidak memerlukan perawatan dan instalasi yang mahal, dan 4) unsur hara dari pupuk kompos ini akan bertahan lama jika dibandingkan dengan unsur hara dari pupuk buatan (Basriyanta, 2007).

Kompos mempunyai beberapa sifat yang menguntungkan antara lain (Indriani, 2008):

1. Memperbaiki struktur tanah berlempung sehingga menjadi ringan

2. Memperbesar daya ikat tanah berpasir sehingga tanah tidak berderai

3. Menambah daya ikat air pada tanah

4. Memperbaiki drainase dan tata udara dalam tanah

5. Mempertinggi daya ikat tanah terhadap zat hara

6. Mengandung hara yang lengkap, walaupun jumlahnya sedikit (jumlah hara ini tergantung dari bahan pembuat pupuk organic)

7. Membantu proses pelapukan bahan mineral

8. Memberi ketersediaan bahan makanan bagi mikroba

9. Menurunkan aktivitas organism yang merugikan

Pada saat penyuluhan diberikan juga informasi mengenai pentingnya lahan pekarangan dengan tanaman agroforestri. Dengan beragroforestri penduduk menmiliki tabungan masa depan. Program penanaman sengon yang dicanangkan oleh Bapak Bupati Kepahiang dapat dilakukan dengan ikut menanam tanaman per tanian yang dapat dipanen sebelum panen tanaman sengon.

Para peserta kegiatan juga memberi masukan mengenai bagaimana menanggulani limbah kulit biji kopi mengingat usaha kopi bubuk juga merupakan salah satu usaha yang banyak dilakukan oleh penduduk Desa Tebat Monok. Dengan adanya masukan tersebut dapat dirancang mengenai tema pengandian pada tahun anggaran mendatang. Bapak Kepala Desa Tebat Monok juga menginginkan adanya evaluasi dari pihak LPPM UNIB setiap tahun mengenai kegiatan pengabdian yang telah dilakukan oleh Tim Pengabdian UNIB.

Permasalahn yang dijumpai pada saat kegiatan pengabdian adalah kesulitan dalam menentukan jadwal kegiatan mengingat kontrak kegiatan yang baru ditandatangani Bulan Juli berbarengan dengan Bulan puasa yang dilanjutkan dengan Bulan Syawal yang banyak dipakai penduduk untuk menyelenggarakan pesta pernikahan. 


\section{Kesimpulan}

\section{KESIMPULAN DAN SARAN}

Pembuatan pupuk kompos cair dari buah limbah di Sentra Buah-buahan Desa Tebat Monok meruapakan salah satu langkah yang tepat dalam mengolah buah limbah yang cepat membusuk (papaya). Pembuatan pupuk kompos cair ini disamping menambah ketrampilan para pedagang buah dalam mengelolala limbah juga dapat dijadikan salah satu usaha untuk menambah pendapatan para pedagang buah di Desa Tebat Monok.

\section{Saran}

Untuk kegiatan pengabdian yang akan datang disarankan untuk melakukan pengelolaan limbah kulit biji kopi yang belum termanfaatkan oleh penduduk desa Tebat Monok Kecamatan Kepahiang.

\section{DAFTAR PUSTAKA}

Basriyanta, 2007, Memanen Sampah, Kanisius, Yogyakarta.

Hadisuwito, S., 2010, Membuat Pupuk Kompos Cair, Agromedia Pustaka, Jakarta.

Indriani, YH, 2008, Membuat Kompos Secara Kilat, Penebar Swadaya, Jakarta.

Suryati, T, 2009, Bijak dan Cerdas Mengolah Sampah: Membuat Kompos dari Sampah Rumah Tangga, Agromedia, Jakarta.

Tim Penulis PS., 2008, Penanganan dan Pengolahan Sampah, Penebar Swadaya, Jakarta. 